\title{
Manajemen Komunikasi Proyek: Studi Kasus Perusahaan Berbasis Engineering, Procurement, Construction dan Manufacturing (EPCM) Kawasan Industri Jababeka Cikarang
}

\author{
Annisa $^{1}$ \\ ${ }^{1}$ Staf Pengajar Program Studi Teknik Sipil, ITSB. \\ e-mail: annisaica@gmail.com
}

\begin{abstract}
Abstrak
Penelitian ini bertujuan untuk mengetahui sejauh mana peran komunikasi menjadi faktor kesuksesan proyek dan variable komunikasi apa saja yang mendukung kesuksesan proyek. Studi kasus dilakukan pada satu perusahaan berbasis EPCM di Kawasan Industri Jababeka, PT. IPK. Metode yang digunakan kualitatif dengan observasi, wawancara, dan studi literatur. Observasi dilakukan untuk mengamati tim berkomunikasi. Wawancara dilakukan kepada key persona. Studi literatur dilakukan untuk pengumpulan materi dan pemahaman obyek yang diteliti. Observasi langsung di lapangan dilakukan tanpa mengganggu proyek. Metode komunikasi secara elektronik merupakan metode yang efektif digunakan. Secara umum penggunaan metode untuk berkomunikasi cukup baik. Distribusi informasi internal menggunakan email, dan WhatsApp.
\end{abstract}

\begin{abstract}
This study aims to find out how far the role of communication is a success factor of a project and what are the communication variables that support the success of a project. Case studies were conducted at an EPCM-based company in the Jababeka Industrial Estate, PT. IPK. The approach used is qualitative, with methods of observation, interviews, and literature studies. Observation is carried out in order to observe the way the team communicates, interviews carried out on key persona. The literature study was conducted aimed at collecting data and for understanding the study object. Direct observation in the field is carried out without disrupting the project. The results of the study show that the method of electronic communication is an effective method to use. In general, the use of methods for communicating is quite good. Internal information distribution using email, and WhatsApp.
\end{abstract}

Kata-kunci : EPCM, komunikasi, manajemen, proyek,

\section{PENDAHULUAN}

Dua dekade yang lalu, suatu proyek dikatakan sukses apabila dapat memenuhi tiga kendala kegiatan proyek yaitu: 1) waktu, 2) biaya, dan 3) pelaksanaan. Saat ini suatu proyek yang sukses tidak hanya dapat memenuhi batasan tersebut. Proyek yang sukses yaitu proyek yang dapat memenuhi batasan berikut, yaitu: 1) sesuai waktu yang dialokasikan, 2) sesuai dengan biaya yang dianggarkan, 3) dilaksanakan dengan tepat sesuai tingkat spesifikasi tertentu, 4) hasilnya dapat diterima dengan baik oleh pengguna, 5) dengan sedikit perubahan lingkup pekerjaan atau dengan perubahan lingkup pekerjaan yang disepakati kedua belah pihak, 6) tanpa mengganggu berjalannya kegiatan utama organisasi, dan 7) tanpa merubah budaya perusahaan (Kerzner, 2010). Seperti yang telah dijabarkan, bahwa proyek yang dikatakan sukses saat ini dibandingkan dua dekade yang lalu mempunyai lebih banyak kriteria yang perlu dipenuhi. Untuk mencapai hal tersebut, dibutuhkan manajemen proyek yang baik dimana salah satu di antaranya 
adalah pengelolaan dan pelaksanaan manajemen komunikasi proyek.

Komunikasi telah diketahui sebagai salah satu faktor penting yang dapat menyebabkan gagal atau sukses nya suatu proyek (Rose, 2013). Komunikasi berperan penting dalam mencapai tujuan tersebut. Komunikasi menurut ruang lingkupnya dapat dibagi menjadi dua bagian utama, yaitu: komunikasi internal dan komunikasi eksternal. Berjalannya komunikasi internal dan komunikasi eksternal secara baik dapat mendukung terciptanya hubungan yang baik dengan customer.

Dalam penelitian ini akan dibahas mengenai komunikasi internal dan komunikasi eksternal, dengan pembahasan lebih mendalam pada komunikasi internal. Di dalam organisasi sendiri, bila proses komunikasi internal tidak baik, maka akan menimbulkan perbedaan yang tidak sesuai harapan, sampai perbedaan pemahaman tentang apa yang dihasilkan pada akhir proyek, orang menjadi tidak siap ketika terjadi perubahan, dan tidak mengetahui secara jelas informasi mengenai status proyek dan setiap anggota tim tidak mengetahui apa yang diharapkan dari mereka (Alexandra-Mihaela et al., 2013).

Rumusan masalah penelitian ini adalah: "Apakah pekerja PT. IPK memahami proses, manfaat pentingnya menjalankan manajemen komunikasi efektif?". Penelitian ini bertujuan untuk mengetahui dua hal, yaitu: (1) sejauh mana peran komunikasi menjadi salah satu faktor kesuksesan dalam suatu proyek, dan (2) variable komunikasi apa saja yang mendukung kesuksesan proyek. Sedangkan tujuan dari adanya manajemen komunikasi proyek adalah untuk membuat semua informasi proyek yang beredar baik secara umum sampai masalah detail dapat sampai tepat waktu sesuai dengan yang ditentukan. Manajemen komunikasi proyek yang tepat merupakan kunci dari keberhasilan proyek.
Penelitian dibatasi pada contoh studi kasus satu perusahaan berbasis engineering, procurement, construction dan manufacturing yang berlokasi di Kawasan Industri Jababeka, yaitu PT. IPK. Hasil temuan ini nantinya akan berguna bagi manajemen komunikasi di perusahaan berbasis engineering, procurement, construction dan manufacturing pada umumnya dan PT. IPK pada khususnya. Penelitian ini juga dapat menjadi referensi untuk penelitian sejenis dalam bidang manajemen dan rekayasa konstruksi.

\section{STUDI LITERATUR}

\section{Hubungan Komunikasi dan Manajemen Proyek}

Secara umum, pengertian komunikasi ditinjau dari bidang keilmuan merupakan suatu panduan bagi manajer selama proses suatu kegiatan dalam pemecahan persoalan meliputi konflik antara anggota tim, evaluasi secara kritis terhadap situasi tertentu dan hasil tertentu (Ten, 2017). Komunikasi adalah dasar dari manajemen proyek karena komunikasi mengintegrasikan biaya, mutu, ruang lingkup untuk mencapai mutu produk yang dihasilkan. Komunikasi dibutuhkan untuk berkomunikasi secara efektif di ketiga area biaya mutu dan waktu yang dikenal sebagai bagian dari batasan proyek (Zulch, 2014). Dengan demikian sangat erat dan mendasar hubungan antara komunikasi dengan manajemen suatu proyek. Komunikasi merupakan kunci untuk mencapai manajemen proyek yang efektif (Samakova et al., 2016).

Manajemen komunikasi proyek merupakan aspek yang penting dalam manajemen proyek. Hal ini dikarenakan komunikasi yang efektif merupakan jembatan yang menghubungkan antara stakeholder dengan budaya dan latar belakang organisasi yang berbeda, keahlian yang berbeda, sudut pandang dan minat yang berbeda, dimana akan berpengaruh terhadap pelaksanaan proyek (PMBOK, 2013). Tanpa 
Manajemen Komunikasi Proyek:

Studi Kasus Perusahaan Berbasis Engineering, Procurement,

Construction dan Manufacturing (EPCM) Kawasan Industri Jababeka

Cikarang

komunikasi yang baik, proyek dapat tidak tepat guna, mutu dan waktu. Hal ini tentu sangat dihindari dalam sebuah proyek, karena akan dapat menimbulkan kerugian. Hal ini penting mengingat informasi adalah kekuatan yang perlu dipahami sebagai kunci kesuksesan proyek (Badiru, 2008).

\section{Manajemen Komunikasi Proyek}

Sejak 1956, Kenneth Boulding telah mengidentifikasikan bahwa komunikasi adalah masalah yang dapat timbul saat sistem integrasi (Kerzner, 2010). Manajemen komunikasi proyek merupakan salah satu area pengetahuan project management. PMBOK Guide, the project management body of knowledge digunakan sebagai salah satu acuan manajemen proyek, dimana salah satu area pengetahuannya adalah manajemen komunikasi proyek.

Manajemen komunikasi proyek meliputi semua proses yang memastikan kesesuaian dan ketepatan dalam perencanaan, pengumpulan, pembuatan, penyebaran, penyimpanan, pengembalian, pengelolaan, pengontrolan, pengamatan, dan status dari informasi proyek (Rose, 2013). Dalam pelaksanaannya terdapat tiga kelompok proses manajemen komunikasi proyek: (1) Perencanaan, (2) Pengelolan, dan

Pengendalian.

Perencanaan adalah proses pengembangan dan pendekatan komunikasi proyek berdasarkan informasi kebutuhan dan ketentuan stakeholder, dan ketersediaan aset organisasi. Pada saat perencanaan para stakeholder harus sudah menentukan basic communication flow.

Pengelolan adalah proses pembuatan, penyebaran, penyimpanan, pengembalian, pengelolaan, pengontrolan, pengamatan, dan posisi dari informasi proyek sesuai manajemen komunikasi yang direncanakan. Sebagai contoh kontraktor utama harus sudah membuat jalur komunikasi antara owner dan sub vendor yang akan menerima instruksi kerja darinya.

Pengendalian adalah Proses pemantauan dan pengontrolan komunikasi tentang seluruh project life cycle untuk memastikan informasi yang dibutuhkan sesuai dengan kebutuhan stakeholder proyek. Sebagai contoh, owner tidak dapat memerintah langsung sub vendor, karena fungsi tersebut ada di kontraktor utama.

Ten (2017) telah melakukan penelitian tentang faktor komunikasi internal apa saja yang paling penting dalam mendukung kesuksesan suatu proyek, yaitu: 1) Kejelasan (konten komprehensif dan terstruktur dengan baik), 2) Informasi yang disampaikan dapat dipercaya, 3) Periodisitas (intensitas komunikasi), 4) Keringkasan yg padat isinya (cara sintetis dan jelas untuk menyampaikan informasi), 5) Waktu (tenggat waktu yang wajar dan kesesuaian perubahan posisi), 6) Bahasa (bahasa umum, dipahami oleh semua orang), 7) Formalitas (adopsi model formal dan template untuk komunikasi), 8) Umpan balik (kritik, proposal, komentar, penilaian), 9) Kelengkapan (ketersediaan data semua diperlukan), 10) menyimpan (memiliki akses ke data sebelumnya), 11) Transparansi (setelah semua orang yang terlibat dan menyadari tugas), 12) Keamanan (kerahasiaan). Terkait dengan komunikasi organisasi dalam suatu proyek, kejelasan suatu penyampaian pesan dan kecepatan pemberian umpan balik menjadi hal yang penting. Hal ini karena suatu pesan dapat dikatakan efektif ketika umpan balik yang diberikan oleh komunikan (penerima pesan) sesuai dengan harapan komunikator (pemberi pesan).

\section{III.METODE PENELITIAN}

Metode Analisis Data 
Metode analisis data yang digunakan dalam penelitian ini adalah pendekatan secara kualitatif. Metode ini digunakan untuk memberikan informasi aktual mengenai manajemen komunikasi yang terjadi di PT. IPK saat mengerjakan suatu proyek. Metode analisis data dengan pendekatan kualitatif digunakan karena alasan efektif dan terukur untuk menganalisis data yang didapat dari studi literatur dan hasil observasi. Hasil observasi di lapangan dengan metode wawancara dianalisis melalui hasil transkip wawancara yang telah dilakukan dengan beberapa manager di PT. IPK. Observasi di lapangan juga dilakukan untuk pengamatan langsung informasi yang beredar di perusahaan.

\section{Metode Pengumpulan Data}

Metode yang digunakan untuk pengumpulan data adalah observasi, wawancara, dan studi literatur. Studi literatur dilakukan dengan cara mencari teori terkait tentang manajemen komunikasi proyek. Pencarian teori bersumber pada buku, jurnal, prosiding, artikel, dan karya tulis ilmiah lainnya. Tujuan dari studi literatur ini adalah untuk menganalisa proses manajemen komunikasi yang terjadi di dalam proyek.

Disamping metode studi literatur, dilakukan juga metode observasi di lapangan untuk metode pengumpulan data. Observasi dilakukan selama satu bulan pada Agustus 2018 di PT. IPK, yang bertujuan untuk memberikan peningkatan pemahaman melalui analisa tahap awal yang diambil berdasarkan dokumen perusahaan dan penjelasan dari pihak PT.

IPK. Penjelasan yang didapat berupa penjelasan satu arah dan wawancara dari pihak PT. IPK. Tujuan dari observasi di lapangan adalah untuk mengetahui apakah pihak pekerja PT. IPK memahami proses manajemen komunikasi proyek dan isu apa saja yang menjadi kendala dalam komunikasi baik secara internal maupun eksternal.

Pengumpulan data dengan metode wawancara dilakukan dua tahap dalam satu sesi wawancara dengan pertanyaan yang terstruktur di tahap pertama dan pertanyaan yang semi terstruktur di tahap kedua. Pada tahap kedua wawancara dilakukan dengan metode impromptu. Metode ini dilakukan untuk menggali lebih dalam informasi dari jawaban-jawaban para terwawancara terkait komunikasi dalam proyek. Terlihat pada Tabel 1. wawancara dilakukan kepada lima manajer departemen yang ada di PT. IPK, yaitu manajer departemen project, manajer departemen quality control quality assurance (QCQA), manajer departemen finance, manajer departemen marketing dan head of business strategy department. Wawancara dengan lima secara internal dan eksternal, juga telah cukup memcerminkan proses manajemen komunikasi proyek yang berjalan di PT. IPK.

Dimulai dari departemen marketing yang lebih banyak berkomunikasi secara eksternal kepada customer saat mendapatkan proyek, kemudian departemen proyek yang cenderung melakukan komunikasi internal maupun eksternal ketika proyek berlangsung, departemen QCQA yang lebih banyak melakukan komunikasi secara internal antar departemen di dalam organisasi pada saat proses pengendalian mutu, dan departemen finance yang lebih banyak berinteraksi internal dengan pihak manajemen di organisasi proyek saat menyelesaikan target keuangan tertentu.

\section{IV.HASIL DAN PEMBAHASAN}

Interaksi komunikasi internal antara individu membentuk perilaku organisasi, dengan demikian, salah satu fungsi utama manajemen 
Tabel 1. Data Wawancara PT. IPK.

\begin{tabular}{cccccc}
\hline Wawancara & Nama & Departemen/Jabatan & $\begin{array}{c}\text { Umur } \\
\text { (Tahun) }\end{array}$ & $\begin{array}{c}\text { Durasi } \\
\text { (Menit, } \\
\text { Detik) }\end{array}$ & Media \\
\hline 1 & Salman & Project Manager & 34 & $35^{\prime} 12^{\prime \prime}$ & Recorder \\
\hline 2 & Fauzan & QC \& QA Manager & 29 & $30^{\prime} 15^{\prime \prime}$ & Recorder \\
\hline 3 & Rulyana & Finance Manager & 27 & $28^{\prime} 15^{\prime \prime}$ & Recorder \\
\hline 4 & Syamsudin & Marketing Manager & 33 & $32^{\prime} 13^{\prime \prime}$ & Recorder \\
\hline 5 & Irvan & Head of Business Strategy Department & 30 & $25^{\prime} 05^{\prime \prime}$ & Recorder \\
\hline
\end{tabular}

untuk menyediakan komunikasi yang efisien di sebuah perusahaan (Ten, 2017). Rumusan masalah dalam penelitian ini akan terjawab dengan pengembangan model yang menggambarkan situasi penggunaan komunikasi di PT. IPK. Pengembangan model didapat dari analisis pengambilan data yang dihasilkan melalui wawancara.

Metode untuk berkomunikasi meliputi metode: tertulis, elektronik, oral, visual, nonverbal (Dow \& Taylor, 2010). Qusef \& Ismail (2016) membedakan alat untuk komunikasi secara tradisional dan secara media sosial. Alat komunikasi secara tradisional termasuk: penggunaan hard copy, panggilan telepon, pesan suara, email, pertemuan, dan website. Metode komunikasi yang efektif di PT. IPK adalah tertulis, elektronik, oral dan visual. Tabel 2. menjelaskan penerapan dari sisi metode komunikasi di PT. IPK. Kecenderungan penggunaan metode yang dipakai oleh setiap departemen di PT. IPK saat mengerjakan suatu proyek berbeda-beda. Hal ini dipengaruhi oleh ruang lingkup komunikasi dan informasi yang beredar di departemen masingmasing.

Qusef \& Ismail (2016) membahas media sosial untuk alat komunikasi utama. Penggunaan media social sebagai alat untuk berkomunikasi di PT. IPK sudah mulai digunakan sejak tahun 2015. Sosial media adalah salah satu dari grup aplikasi yang berbasis internet yang membangun ideologi dan dasar teknologi Web 2.0 yang memungkinkan untuk berkreasi dan pertukaran konten (Kaplan \& Haenlein,
2010, p. 61). Dalam perusahaan ini aplikasi yang digunakan adalah WhataApp. WhatsApp adalah sebuah aplikasi berbasis web untuk berkirim pesan secara instan, video, dan panggilan telpon. Digunakan secara khusus untuk penggunaan pesan obrolan secara pribadi dan secara grup. Penggunaan WhatsApp dapat diakses melalui media PC pribadi dan handphone. Adapun kegunaan lain dari WhatsApp adalah kemungkinan untuk mengetahui apakah pesan yang dikirim sudah terkirim dan dibaca oleh penerima (Ten, 2017).

Dalam hal penggunaan WhatsApp: "fast deliver but does not mean fast response". Permasalahan project dapat tersampaikan secara langsung tetapi belum tentu pihak yang dituju langsung membaca pesan tersebut dikarenakan orang yang bersangkutan tidak selalu membawa handphone-nya kemanapun bersama dengan dirinya. Solusi dari permasalahan ini adalah tetap diperlukan follow up secara langsung dan intense memastikan bahwa pihak yang bersangkutan membaca masalah proyek tersebut.

Di PT. IPK untuk setiap proyek yang sedang berlangsung dibuat satu buah grup dengan anggota berisikan pihak-pihak yang terkait dari semua divisi dalam proyek tersebut. Keuntungan dengen adanya proyek grup ini adalah semua orang yang terlibat mendapatkan update milestone proyek secara tersebut secara cepat dan seragam. Kelemahannya adalah walaupun ada pertanyaan terkait 
salah satu pihak/divisi yang dapat langsung ditanyakan di grup, terkadang pesan itu tertimpa dengan pesan lain sehingga perlu di follow up secara pribadi. bahwa komunikasi internal adalah

Tabel 2.Metode Komunikasi Efektif di PT. IPK.

\begin{tabular}{cccccccc}
\hline Metode & Tertulis & $\sqrt{ }$ & $\sqrt{ }$ & $\sqrt{ }$ & & & Musiness \\
Strategy & Surat, Memo, Notulen \\
\hline & Elektronik & $\sqrt{ }$ & $\sqrt{ }$ & $\sqrt{ }$ & $\sqrt{ }$ & $\sqrt{ }$ & Email, Aplikasi (WhatsApp) \\
\hline Oral & $\sqrt{ }$ & $\sqrt{ }$ & $\sqrt{ }$ & $\sqrt{ }$ & $\sqrt{\text { Meeting, Diskusi, }}$ \\
& Visual & $\sqrt{ }$ & & & & & $\begin{array}{c}\text { Perbincangan (face-to-face/ } \\
\text { telepon) }\end{array}$ \\
\hline Level & Internal & $\sqrt{ }$ & $\sqrt{ }$ & $\sqrt{ }$ & $\sqrt{ }$ & $\sqrt{ }$ & Presentasi \\
\hline & Eksternal & $\sqrt{ }$ & & & $\sqrt{ }$ & $\sqrt{ }$ & \\
\hline
\end{tabular}

Memudahkan untuk pengiriman gambar, dokumen, maupun data pesan dari pemberi kerja. Ini yang dirasa sangat menguntungkan karena kebanyakan pemerintah kerja (eksternal communication) berkomunikasi dengan menggunakan WhatsApp sehingga dapat dengan mudah "screen shoot" pesan dari pemberi kerja (eksternal) di forward ke grup project (internal). Perusahaan tidak perlu mengeluarkan investasi untuk alat komunikasi karena WhatsApp terpasang pada setiap handphone pribadi pegawai.

Email masih banyak digunakan baik untuk komunikasi internal dan eksternal. Perusahaan perlu investasi pada perangkat pendukung komunikasi seperti internet, PC dan official email berbayar. Email biasa dibaca menggunakan PC jarang sekali dibaca menggunakan handphone pribadi, dikarenakan penggunakan email dirasa lebih formal daripada WhatsApp.

Mengapa komunikasi internal penting? Komunikasi internal mempunyai dua tujuan utama, yaitu: (1) menjaga kesadaran setiap pegawai akan tugas dan aturan-aturan umum, dan (2) menciptakan budaya perusahaan. Budaya perusahaan (prinsip, perilaku dan nilai-nilai) yang terkandung dalam satu perusahaan dibentuk oleh prinsip-prinsip, perilaku dan nilai-nilai yang ditumbuhkan baik oleh shareholder maupun stakeholder internal (Ten, 2017). Pendapat lain menjelaskan komunikasi antara manajer strategis dan pemangku kepentingan internal yang dirancang untuk mempromosikan komitmen dan rasa milik organisasi, untuk mengembangkan kesadaran lingkungannya yang berubah, dan pemahaman yang berkembang bertujuan." (Welch \& Jackson, 2007, p.186).

Tujuan utama komunikasi internal tersebut dijelaskan oleh Richmond et al. (2005, p.25). memiliki enam fungsi utama yaitu: (1) fungsi informasi yang memungkinkan seluruh pegawai dapat menerima informasi secara lengkap yang dibutuhkan untuk menyelesaikan tugas,

fungsi regulasi berartikulasi dengan kode perilaku dan kebijakan perusahaan, peraturan dan norma-norma, (3) komunikasi sebagai fungsi integrasi menempatkan penekanan pada koordinasi proses-proses yang dilakukan oleh departemen yang berbeda atau karyawan terhadap satu tujuan, (4) fungsi manajerial ditujukan untuk membangun komitmen melalui membangun dapat dipercaya dapat diandalkan hubungan antara karyawan, (5) fungsi persuasif yang berasal dari satu manajerial, berusaha untuk meyakinkan dan memotivasi orang untuk memenuhi tugas-tugas mereka dalam cara yang tepat dan sesuai dengan prosedur yang diperlukan dan (6) fungsi sosialisasi antar karyawan dalam 
Manajemen Komunikasi Proyek:

Studi Kasus Perusahaan Berbasis Engineering, Procurement,

Construction dan Manufacturing (EPCM) Kawasan Industri Jababeka

Cikarang

perusahaan, memberikan rasa memiliki terhadap entitas perusahaan.

Komunikasi internal sebagai spesialisasi belum ada sampai 1990-an (Verčič, et al., p, 2012.223), hal ini dapat dipandang bahwa penyebabnya adalah kurangnya pemahaman teoritis bagaimana komunikasi internal dapat berkontribusi ke efektivitas organisasi, Grunig (1992, p.536). Selanjutnya, bukti empiris lainnya yang menjelaskan bahwa komunikasi internal sukses mendukung dan mengembangkan karyawan memahami peluang dan ancaman, organisasi sasaran dan tujuan, memfasilitasi interaksi antara senior manajer dan karyawan, mempromosikan komitmen organisasi dan memberikan kontribusi untuk membangun rasa positif identifikasi karyawan (Quinn \& Hargie, 2004; Robson \& Tourish, 2005; Welch, 2012).

Melanjutkan dari teori di atas, komunikasi internal adalah sistem yang kompleks yang dapat diukur dari perspektif yang berbeda, tergantung pada sudut menarik seorang peneliti, dan itu semakin diakui sebagai kunci sukses (Ten, 2017). Komunikasi internal yang efisien di sebagian besar bergantung pada orangorang mencapai informasi sesuai dalam format yang berguna dan diterima mereka (Welch, 2012). Dari perspektif penerima, media komunikasi internal dapat digolongkan oleh format dalam tiga kategori utama: cetak/hard copy (diakses pada kertas), elektronik (akses melalui perangkat teknologi), dan tatap muka (interpersonal) (Welch, 2012).

\section{Metode Komunikasi Efektif}

Metode komunikasi secara elektronik dan oral merupakan metode yang paling efektif sebagai metode komunikasi yang digunakan di manajemen proyek. Departemen project dalam struktur organisasi perusahaan PT. IPK merupakan departemen yang berlaku sebagai perencana dan kontrol proyek saat pelaksanaan proyek.

\begin{abstract}
Metode Penyebaran Informasi Secara Efektif

Rose (2013) membagi tiga metode untuk penyebaran informasi, dua diantaranya efektif digunakan di PT. IPK, yaitu: komunikasi interaktif (meeting, telepon, pesan instan) dan push communication (surat, memo, laporan, email, fax).
\end{abstract}

\section{Penggunaan Teknologi Komunikasi yang Efektif}

Penyebaran informasi setelah personal computer/laptop dan telepon seluler, penggunaan aplikasi WhatsApp merupakan aplikasi yang sering digunakan dan sangat membantu dalam penyebaran informasi secara efektif. Penggunaan aplikasi ini aktif digunakan dalam satu tahun terakhir untuk mengontrol dan memberikan isu-isu berkaitan proyek. Aplikasi tersebut digunakan untuk penyebaran data proyek kepada satu grup dimana semua pihak yang terlibat dalam proyek tersebut ada dalam grup tersebut. Penggunaan aplikasi dalam penyebaran informasi sejalan dengan temuan penelitian tentang teknologi komunikasi dalam pertukaran dokumen di proyek konstruksi yang diteliti oleh Mandicak dan Mesaros (2016).

\section{Kendala Dalam Komunikasi}

Kendala yang terjadi yaitu apabila melakukan komunikasi secara tidak langsung menggunakan aplikasi WhatsApp, kadang informasi itu tidak terbaca atau termonitor oleh pihak yang bersangkutan. Hal ini menjadimasalah ketika informasi yang dibutuhkan tersebut memiliki tingkat urgensi yang tinggi. Solusi dari permasalahan ini baiknya dilakukan komunikasi secara langsung untuk memastikan informasi tersebut dapat diterima dengan baik. Follow-Up dan respon dari pemberi dan penerima informasi merupakan bagian dari komunikasi yang efektif. Penggunaan metode elektronik dan face to face dalam pertukaran dokumen memiliki tingkat 
penggunaan yang sama penting dan sering (Mandicak \& Mesaros, 2016).

\section{Social Media}

Penggunaan sosial media dalam pengerjaan proyek di PT. IPK sangat terfokus pada WhatsApp. Penggunaan WhatsApp terfokus untuk penyebaran informasi dan koordinasi proyek. Ten (2017) menjelaskan bahwa pihak shareholder harus menggunakan social media untuk melancarkan komunikasi dan kolaborasi dari pekerja-pekerjanya. Hal ini nantinya akan membentuk suatu budaya perusahaan yang baru, karena terdapat pergeseran nilai-nilai, perilaku dan prinsip.

\section{V.KESIMPULAN}

Secara umum penggunaan metode untuk berkomunikasi pada proyek di PT. IPK sudah cukup baik. Distribusi informasi di internal PT. IPK sendiri pada umumnya email, dan WhatsApp grup. Hal ini berdasarkan respon dari wawancara. Penggunaan social media memberi banyak keuntungan antara lain: (1) memberikan kemudahan untuk berinteraksi dengan pihak yang tidak berada dalam jangkauan dekat, memberikan kemudahan berkomunikasi secara terbuka dan transparan karena percakapan tersimpan secara digital, (2) memberikan kemudahan komunikasi tanpa batasan waktu, (3) biaya murah, (4) penggunaan aplikasi dapat diakses mudah dan (5) perusahaan tidak perlu menyediakan investasi untuk alat, karena saat ini pada umumnya orang sudah memiliki smart phone, namun memberikan suatu kendala baru dimana tidak terciptanya interaksi sosial secara nyata seperti follow up informasi atau melakukan komunikasi face to face yang seharusnya dilakukan sehingga ini menjadi kendala komunikasi tidak berjalan efektif. Variabel komunikasi yang berpengaruh: metode; (2) media; (3) ruang lingkup internal/eksternal dan (4) job desc setiap departemen. Penulis berpendirian bahwa penelitian ini dapat berkontribusi dalam pemahaman komunikasi proyek dengan social media sebagai salah satu media utama untuk berkomunikasi yang diyakini memiliki subjek relevansi tinggi pada praktek manajemen proyek.

\section{Ucapan Terimakasih}

Terimakasih kepada pihak Institut Teknologi dan Sains Bandung (ITSB) yang telah mendanai penelitian ini, dan pihak PT. IPK yang telah memberikan ijin untuk menjadikan perusahaannya sebagai studi kasus penelitian ini.

\section{Daftar Pustaka}

Alexandra-Mihaela, P., \& Danut, D. D. 2013. The Measurement And Evaluation Of The Internal Communication Process In Project Management. Annals of the University of Oradea, Economic Science Series, 22(1).

Badiru, A. B. 2008. Triple C model of project management: Communication, cooperation, and coordination. CRC Press.

Grunig, J. E., \& White, J. 1992. The effect of worldviews on public relations theory and practice. Excellence in public relat ions and communication management, 31-64.

Kaplan, A. M., \& Haenlein, M. 2010. Users of the world, unite! The challenges and opportunities of Social Media. Business horizons, 53(1), 59-68.

Kerzner, H. 2010. Organizing and staffing the project office and team. Project Management: A Systems Approach to Planning, Scheduling, and Controlling, 141-144.

Mandičák, T., Mesároš, P., \& Selín, J. 2016. Document management systems for data sharing in the construction project management. Czasopismo Techniczne, 2016(Budownictwo Zeszyt 1-B (6) 2016), 51-56.

Quinn, D., \& Hargie, O. 2004. Internal communication audits: a case study. Corporate Communications: An International Journal, 9(2), 146-158.

Qusef, A., \& Ismail, K. 2016, July. Social media in project communications 
Manajemen Komunikasi Proyek:

Studi Kasus Perusahaan Berbasis Engineering, Procurement,

Construction dan Manufacturing (EPCM) Kawasan Industri Jababeka

Cikarang

management. In 2016 7th International Conference on Computer Science and Information Technology (CSIT) (pp. 1-5). IEEE.

Richmond Virginia, P., McCroskey, J. C., \& McCroskey, L. L. 2005. Organizational communication for survival making work. United States of America: Pearsom Education.

Robson, P. J., \& Tourish, D. 2005. Managing internal communication: an organizational case study. Corporate Communications: An International Journal, 10(3), 213-222.

Rose, K. H. 2013. A Guide to the Project Management Body of Knowledge (PMBOK® Guide)—Fifth Edition. Project management journal, 44(3), e1-e1.

Samáková, J., Šujanová, J., \& Špirková, M. 2016. Utilisation and Improvement of the Initialisation of Project Communication Processes During the Management of Projects in Industrial Enterprises in Slovakia. Research Papers Faculty of Materials Science and Technology Slovak University of Technology, 24(37), 63-72.
Ten, Y. 2017. Social Media as an Internal Communication Tool in Project Management Practices: Exploring an Impact of Social Media Use on Employee Communication in Small and Mediumsized Companies in Uzbekistan.

Verčič, A. T., Verčič, D., \& Sriramesh, K. 2012. Internal communication: Definition, parameters, and the future. Public relations review, 38(2), 223-230.

Welch, M., \& Jackson, P. R. 2007. Rethinking internal communication: a stakeholder approach. Corporate Communications: An International Journal, 12(2), 177-198.

Welch, M. 2012. Appropriateness and acceptability: Employee perspectives of internal communication. Public Relations Review, 38(2), 246-254.

Dow, William P. M. P., \& Taylor, B. 2010. Project management communications bible. Vol. 574. John Wiley \& Sons.

Zulch, B. G. 2014. Communication: The foundation of project management. Procedia Technology, 16, 1000-1009. 